\title{
Eksistensi Ulama Minang dan Ulama Jawa dalam Mengembangkan Islam di Bengkulu
}

\author{
Ismail dan Aziza Aryati \\ IAIN Bengkulu \\ Jl. Raden Patah, Kelurahan, Pagar Dewa, Selebar, Pagar Dewa, Kec. Selebar, Kota Bengkulu \\ ismailmunir1972@gmail.com
}

\begin{abstract}
The Existence of Minang and Javanese Ulama in Developing Islam in Bengkulu. According to Hiroko Horikoshi, the role of the most valuable and primary ulama was related to his traditional role, namely as the person in charge of maintaining belief (faith). Through the teaching of religious sciences, ulama preserve the practices of the religious orthodoxy of its adherents. Ulema can not be separated from religion and people. Ibn Qoyyim al-Jauziyyah mentioned that the position of the ulama from a sociological point of view was central in the relationship of Islam with his people. That is why, scholars often present themselves as decisive figures in the struggle of Muslims on the historical stage, dealing with government, politics, social, culture and education. The formation of Muslims and their preservation cannot be separated from the role of the ulema. In the meantime, the Muslim community has a stake in the formation of scholars on an ongoing basis. This paper describes the role of ulama in the structure of Bengkulu society. Ulama have a significant function, an ulama has a position as a leader (non-formal) who resides in an Islamic community. He even has the responsibility in providing direction and guidance to the community, both related to religious guidance and various problems faced by the community. Based on this role, a cleric in addition to functioning to instill religious belief and enlightenment (theological functions) he is also a problem solver in society (sociological function).
\end{abstract}

Key Words: Ulama, religious orthodoxy, problem solver

\begin{abstract}
Abstrak: Eksistensi Ulama Minang dan Ulama Jawa dalam Mengembangkan Islam di Bengku$l u$. Menurut Hiroko Horikoshi, peran ulama yang paling bernilai dan utama adalah terkait peran tradisionalnya, yakni sebagai penanggung jawab dalam mempertahankan keyakinan (keimanan). Melalui pengajaran ilmu-ilmu agama, ulama melestarikan praktek-praktek ortodoksi keagamaan para penganutnya. Ulama tidak dapat dipisahkan dari agama dan umat. Ibnu Qoyyim al-Jauziyyah menyebutkan bahwa posisi ulama dari sudut sosiologis sebagai pusat dalam hubungan Islam dengan umatnya. Itulah sebabnya, ulama sering menampilkan diri sebagai figur yang menentukan dalam pergumulan umat Islam di panggung sejarah, berhubungan dengan pemerintahan, politik, sosial, budaya dan pendidikan. Pembentukan Muslim dan kelestariannya tidak dapat dilepaskan dari peran ulama. Dalam pada itu, masyarakat Muslim memiliki andil bagi terbentuknya ulama secara berkesinambungan. Tulisan ini mendeskripsikan peran ulama dalam struktur masyarakat Bengkulu. Ulama memiliki fungsi yang cukup signifikan, seorang ulama memiliki kedudukan sebagai pemimpin (non-formal) yang berdiam pada suatu komunitas masyarakat Islam. Ia bahkan mempunyai tanggung jawab dalam memberikan pengarahan dan bimbingan kepada masyarakat, baik yang terkait bimbingan keagamaan maupun berbagai problematika yang dihadapi masyarakatnya. Berdasarkan peran ini, seorang ulama selain berfungsi memberikan penanaman keyakinan dan pemberi pencerahan keagamaan (fungsi teologis) ia juga sebagai problem solver dalam masyarakat (fungsi sosiologis).
\end{abstract}

Kata Kunci: Ulama, ortodoksi agama, problem solver. 


\section{Pendahuluan}

Secara etimologis, kata ulama (علماء) adalah bentuk plural dari kata ble, yang artinya orang-orang yang mengerti, orang yang berilmu, atau orang yang berpengetahuan. ${ }^{1}$ Berdasarkan pengertian ini, ulama adalah para ilmuan, baik di bidang agama, humaniora, sosial, dan kealaman. Menurut al-Munawar ulama adalah orang-orang yang memiliki pengetahuan luas tentang ayat-ayat Allah baik bersifat kauniyyah (fenomena alam) maupun bersifat Quraniyyah yang mengantar manusia agar memiliki pengetahuan tentang kebenaran, bertakwa, tunduk dan takut kepada Allah. ${ }^{2}$ Dalam perkembangannya term ulama mengandung pengertian yang sempit dan hanya dipergunakan oleh ahli agama. ${ }^{3}$ Karenanya, secara terminologis, ulama berarti orang yang ahli dalam hal atau pengetahuan agama Islam. ${ }^{4}$ Dengan pengertian ini, maka yang dimaksud dengan ulama adalah khusus orang yang mendalam ilmunya tentang agama Islam dengan segala cabangnya, seperti tafsir, hadis, fikih, tauhid, dan lain-lain.

Dalam konteks risalah keagamaan (Islam), ulama mengemban beberapa fungsi, antara lain: 1) Tablig, yaitu menyampaikan pesanpesan agama, yang menyentuh hati dan merangsang pengalaman; 2) Tibyan, yakni menjelaskan masalah-masalah agama berdasarkan kitab suci secara jelas dan transparan; 3) Tahkim, yaitu, menjadikan al-Qur' an sebagai sumber utama dalam memutuskan perkara dengan bijaksana dan adil; 4) Uswatun hasanah, yaitu menjadi tauladan yang baik dalam pengamanan agama. ${ }^{5}$

Menurut Hiroko Horikoshi, peran ulama yang paling bernilai dan utama adalah terkait peran tradisionalnya, yakni sebagai penanggung jawab dalam mempertahankan keyakinan (keimanan). Melalui pengajaran ilmu-ilmu agama, ulama melestarikan praktek-praktek ortodoksi keagamaan para penganutnya. ${ }^{6}$ Ulama tidak dapat dipisahkan dari agama dan umat. Ibnu Qoyyim al-
Jauziyyah menyebutkan bahwa posisi ulama dari sudut sosiologis sebagai pusat dalam hubungan Islam dengan umatnya. Itulah sebabnya, ulama sering menampilkan diri sebagai figur yang menentukan dalam pergumulan umat Islam di panggung sejarah, berhubungan dengan pemerintahan, politik, sosial, budaya dan pendidikan. ${ }^{7}$ Pembentukan Muslim dan kelestariannya tidak dapat dilepaskan dari peran ulama. Dalam pada itu, masyarakat Muslim memiliki andil bagi terbentuknya ulama secara berkesinambungan.

Dalam struktur masyarakat Bengkulu, ulama memiliki fungsi yang cukup signifikan, seorang ulama memiliki kedudukan sebagai pemimpin (non-formal) yang berdiam pada suatu komunitas masyarakat Islam. Ia mempunyai tanggung jawab dalam memberikan pengarahan dan bimbingan kepada masyarakat, baik yang terkait bimbingan keagamaan maupun berbagai problematika yang dihadapi masyarakatnya. Berdasarkan peran ini, seorang ulama selain berfungsi memberikan penanaman keyakinan dan pemberi pencerahan keagamaan (fungsi teologis) ia juga sebagai problem solver dalam masyarakat (fungsi sosiologis).

Institusi sosial-kemasyarakatan yang paling dekat hubungannya dengan ulama adalah institusi pendidikan yang berhubungan dengan statusnya sebagai elite intelektual. Hubungan ulama dan institusi pendidikan hadir dalam bentuk hubungan simbiosis-mutualisme, saling terkait dan saling membutuhkan. Ada dua pola hubungan ulama dan institusi pendidikan Islam, yakni:1) Lembaga pendidikan Islam merupakan sarana transmisi keilmuan bagi para ulama; 2) Institusi-institusi pendidikan formal atau non formal merupakan sarana pembentukan dan pengkaderan ulama.

Dalam hubungannya dengan institusi pendidikan, ulama terlibat sebagai fungsionaris yang mempunyai peran sentral. Peranan tersebut terlihat dalam setiap tahap perkembangan institusi pendidikan Islam dalam berbagai bentuknya seperti ma- 
jlis, halaqah, maktab, kuttab, jami', madrasah, zatuiyyah dan ribat. ${ }^{8}$ Menurut Maqdisi dan Pedersen, lembaga pendidikan dalam bentuk madrasah merupakan institusi pendidikan Islam yang tidak dapat dipisahkan dengan masjid. ${ }^{9}$ Di masjid ulama memainkan peran non formal dalam memberikan pengajaran dan pendidikan pada masyarakat. Ikatan yang terjalin antar ulama sebagai pengajar dan muridnya lebih didasarkan keterikatan moral dalam hubungan yang sakral.

Begitu juga dengan pesantren sebagai lembaga pendidikan agama memiliki peran yang sangat sentral. Pesantren terdiri atas lima pokok elemen, yaitu ulama, santri, mesjid, pondok, dan pengajaran kitab-kitab klasik. Kelima elemen tersebut merupakan ciri khas yang dimiliki oleh pesantren, sekaligus membedakannya dengan lembaga pendidikan dalam bentuk lain. Meski kelima elemen ini saling menunjang eksistensi sebuah pesantren, namun ulama memainkan peran yang begitu sentral di dalamnya. Keberadaan seorang ulama dalam lingkungan sebuah pesantren, laksana jantung bagi kehidupan manusia. Intensitas ulama memperlihatkan peran yang otoriter, disebabkan karena ulamalah sebagai perintis, pendiri, pengelola, pengasuh, pemimpin, dan bahkan sebagai pemilik tunggal. Karenanya, dengan alasan ketokohan ulama tersebut, ada sebagian pesantren yang bubar lantaran ulamanya wafat. ${ }^{11}$

\section{Pembahasan}

\section{A. Letak Geografis Wilayah Melayu Beng- kulu}

Secara geografis, wilayah Bengkulu terletak di sebelah barat Pulau Sumatera bagian Selatan, dengan batas-batasnya; di sebelah Utara, Timur dan Selatan berbatasan dengan wilayah Provinsi Sumatera Barat (Indrapura), Provinsi Jambi (Kerinci), Provinsi Sumatera Selatan dan Provinsi Lampung; di sebelah barat berbatasan dengan samu- dera Indonesia. Secara geologis, wilayah Bengkulu terletak antara daerah perbatuan pretersier, tersier, vulkan dan batuan endapan alluvial. Keadaan kondisi seperti ini banyak memberi pengaruh bagi keadaan bumi dan kehidupan penduduknya. Pada beberapa daerah persebaran batu-batuan ini mengandung barang-barang tambang seperti emas, perak, koalin kuarsa dan lain-lain. Di atas dan di lereng tanah-tanah gunung, para penduduk mereka hidup sebagai petani. Daerah vulkanis seperti di Lembah Semangka dan sepanjang Bukit Barisan merupakan daerah yang sangat subur tanahnya. ${ }^{12}$

Bila mengacu pada awal pembentukan Provinsi Bengkulu, disebutkan bahwa Keresidenan Bengkulu terletak pada bagian barat daerah Sumatera Selatan. Bagian utara berbatasan dengan daerah Jambi, sebelah timur dan selatan berbatasan dengan Lampung dan Palembang, dan sebelah barat berbatasan dengan Lautan Indonesia. ${ }^{13}$ Berdasarkan data yang ada luas wilayah Provinsi Bengkulu mencapai kurang lebih 1.978.870 hektar atau 19.788,7 kilometer persegi, ${ }^{14}$ terdiri dari 9 (sembilan) daerah kabupaten dan satu pemerintahan kota.

Secara administratif, sebagian besar wilayah Provinsi Bengkulu berada pada garis pantai barat Sumatera yaitu; meliputi Kabupaten Mukomuko, Kabupaten Bengkulu Utara, Kabupaten Bengkulu Tengah, Kota Bengkulu, Kabupaten Seluma, Kabupaten Bengkulu Selatan, dan Kabupaten Kaur. Sedangkan wilayah yang berada di posisi dataran tinggi meliputi Kabupaten Rejang Lebong, Kabupaten Lebong dan Kabupaten Kepahiang. ${ }^{15}$

\section{B. Aspek Sosial-Keagamaan Melayu Beng- kulu}

Di negeri ini hampir semua orang Melayu beragama Islam. Meskipun kepercayaan Hindu tersebar luas dan telah ada berabad-abad lamanya, jarang terdengar bahwa orang Melayu beragama Hindu. Yang mana penyebaran agama Hindu dan 
kebudayaannya telah merangkul banyak penganut, terutama di Jawa Timur dan Bali. Sebenarnya pengaruh Islam terhadap orang Melayu telah mendarah daging. Sejak mereka melepaskan kepercayaan animisme-dinamisme dan menerima Islam pada masa Kerajaan Malaka, orang-orang Melayu tidak pernah lagi beralih ke agama lain. Sebelum dan sesudah kedatangan orang-orang Inggris, misi Kristen cukup aktif terutama melalui sekolah-sekolah.

Kendati orang-orang Melayu itu beragama Islam, namun pengaruh kepercayaan tradisional masih melekat kuat di masyarakat, termasuk di wilayah Melayu Bengkulu. Manifestasi dari kepercayaan itu dapat terlihat dalam berbagai aspek kehidupan bangsa Melayu baik segi sosial, ekonomi, politik, medis dan bahkan dalam masalah percintaan sekalipun. Kepercayaan tradisional yang tersebar luas dalam kalangan Melayu dewasa ini merupakan kelanjutan dari sistem kepercayaan sebelum masuknya agama Islam di daerah ini. Sukar sekali merekonstruksi sistem kepercayaan lama, yang didasarkan pada apa yang disebut animisme. Dalam kepercayaan animisme orang percaya bahwa ada beberapa kekuatan adikodrati yang mendiami dan melindungi segala sesuatu di sekitar kehidupan manusia, di gunung-gunung, lereng gunung dan bukit, danau, kali, sungai, lautan, langit, pohon dan batang pohon. Orang lantas memanjatkan berbagai macam permohonan kepada kekuatankekuatan itu melalui orang-orang yang ahli dalam urusan adikodrati itu dan menjadi tempat berlindung semua umat manusia.

Secara sepintas kiranya jelas bahwa kepercayaan animisme bertentangan dengan ajaran Islam. Tetapi dalam realitanya bahwa kepercayaan animism dan dinamisme sampai sekarang masih ada di kalangan masyarakat Melayu. Orang-orang Me- layu dengan keyakinan Islamnya, masih juga mengandalkan kepercayaan tradisioanal itu. Pernyataan itu dapat dijawab jika kita mau melihat sistem kepercayaan atau agama ini dari tiga aspek: ritus, para pemimpin dan ajarannya. Ketiga aspek ini tidak terpisahkan bahkan terkait satu sama lainnya. Dalam setiap aspek tersebut dapat dilaksanakan adanya proses pertentangan dan penyesuaian antara kepercayaan tradisional dan agama Islam.

Pada tingkat ritus keagamaan, kita dapat melihat berbagai bentuk kegiatan yang dilaksanakan oleh masyarakat Melayu. Misalnya, pernikahan (sosial), bertani (ekonomi), dan perawatan orang sakit (medis). Dalam satu pernikahan, banyak dilaksanakan upacara-upacara seperti dengar pendapat (sounding-out), meminang, antar belanja, upacara temu dan duduk bersanding, makan berhadap-hadapan dan sebagainya. Upacara semacam itu telah dilakukan oleh beberapa generasi sebagaimana suatu bagian dari kebudayaan Melayu. Dalam Islam tidak ada pernyataan yang jelas terungkap, apakah hal itu boleh atau tidak boleh dilakukan. Jika ada hal yang bertentangan dengan ajaran Islam, maka mungkin menyangkut masalah pemborosan biaya dalam beberapa upacara, yaitu biaya mubazir yang bersifat kesombongan. Tetapi secara umum, jika upacara-upacara itu dilaksanakan secara biasa saja, maka upacara-upacara itu sangat dianjurkan. Perlu diingat bahwa sekalipun semua upacara tradisional dilakukan dengan cara yang sebaik mungkin, namun pernikahan itu belum dapat dikatakan sah sebelum persaratan Islam terpenuhi, seperti ijab kabul kedua mempelai di depan para saksi. Di antara orang-orang Melayu itu dapat terlihat perpaduan antara ritusritus tradisional dan ritus-ritus Islam. ${ }^{16}$

Dalam kegiatan bertani, juga terdapat 
ritus-ritus yang merupakan bagian dari sistem kepercayaan tradisional yang terkait dengan masalah ekonomi. Ada beberapa upacara untuk setiap tahap dalam kegiatan bertani atau bercocok tanam. Pada waktu tanam, pada waktu tanaman sudah tumbuh, dan pada waktu panen. Sebagai contoh, di beberapa daerah tertentu pada musim tanam padi para petaninya mengumpulkan bibit, beras kuning, dan padi, dan memohon berkah melalui seorang dukun atau pawang. Kemudian bibit padi itu ditanam dengan do'a permohonan agar bibit tersebut dipelihara Yang Maha Kuasa, lalu beras kuning ditaburkan di sawah dengan membaca shalawat tiga kali. Ucapan do'a dan shalawat itu merupakan unsur Islam yang dipadukan dengan upacara tradisional.

Demikian halnya dengan pengobatan satu penyakit. Menurut kepercayaan tradisional penyakit disebabkan oleh roh jahat atau setan yang masuk dalam tubuh manusia melalui ilmu sihir. Cara untuk menyembuhkan penyakit itu adalah dengan mengusir roh jahat oleh seorang ahli kebatinan atau dukun yang memiliki kekuatan gaib. Sambil mengobati orang yang sakit itu ia melakukan do'a ritual, membakar kemenyan dan mengucapkan mantra-mantra. Kadang ia tidak sadarkan diri, dalam keadaan demikian itulah ia dapat mengobati orang sakit. Dalam beberapa cara penyembuhan ditemukan unsur-unsur Islam di dalamnya seperti ucapan bismillah dan pengagungan nama Allah serta nabi di dalam mantra-mantra yang mengandung kekuatan magis. Beberepa do'a penyembuhan lain menggunakan bahasa Arab, ayatayat al-Qur'an serta unsur-unsur kekuatan adikodrati untuk mengusir roh jahat atau jin Muslim.

Aspek kedua menyangkut pemimpin yang mempunyai peranan penting dalam berbagai upacara seperti diuaraikan di atas. Untuk upacara bertani seorang ahli atau dukun memanjatkan doa permohonan dan untuk pengobatan penyakit seorang tabib. Mereka itulah yang berfungsi di dalam sistem kepercayaan tradisional dan yang paling hebat di antara mereka disebut pawang atau bomoh (dukun atau pendoa). Mereka telah memperoleh keahlian dalam ilmu sihir (magis) atau ilmu gaib melalui berbagai cara, antara lain : melalui orang tua mereka, impian atau dengan cara mengasingkan diri atau bertapa. Ilmu sihir itu mengandung rahasia dan hanya sedikit yang berhubungan dengan Islam. Doa dan syair yang dibacakan dan tanda-tanda yang digunakan seorang dukun kadang-kadang dikutip dari Kitab Suci atau menggunakan berbagai sebutan Tuhan. Beberapa di antara mereka tidak mengetahui banyak hal mengenai Islam, tetapi ada juga yang taat beribadah dan mengatakan bahwa sumber pengetahuan mereka adalah Islam, terutama Kitab Suci Al-Quran.

Mereka yang menggunakan Kitab suci al-Quran sebagai sumber keahliannya pada umumnya mudah diterima dalam lingkup pedesaan atau oleh petugas atau pejabat keagamaan seperti imam, guru-guru agama, dan lain-lain. Sedangkan mereka yang tidak menggunakan Al-Qur'an sebagai sumber keahliannya pada umumnya dicurigai, tetapi mereka tetap mendapat tempat istimewa di hati masyarakat Melayu, terutama masyarakat pedesaan. Para pejabat kepercayaan tradisional hidup berdampingan dengan para pejabat agama Islam, masing-masing memainkan peranannya dalam wilayahnya masing-masing. Dalam kenyataannya ada beberapa pejabat agama Islam juga mempunyai peranan penting dalam sistem kepercayaan tradisional.

Aspek ketiga adalah aspek ajaran agama 
atau kepercayaan. Meskipun kelihatannya ada perpaduan antara kepercayaan tradisional dan Islam, dan eksistensi yang sama antara pejabat agama Islam dan pejabat kepercayaan trsdisional, hubungan keduanya cukup berbeda dari aspek ajaran. Menurut ajaran Islam yang prinsipil, Allah itu Esa dan Maha Kuasa, dan merupakan sumber serta penyebab segala sesuatu yang ada. Ia memberi kehidupan dan menyebabkan kematian; menciptakan dan menghancurkan. Kepercayaan bahwa masih ada kekuasaan yang membuat tanaman tumbuh subur atau menyebabkan seseorang sakit atau mati bertentangan dengan ajaran Islam. Dalam kepercayaan tradisional terdapat kepercayaan adanya kekuatan adikodrati yang dapat menyebabkan terjadinya sesuatu; hantu, setan, dan roh jahat. Para pemimpin kepercayaan tradisional mengatakan bahwa mereka dapat menggunakan kekuatan-kekuatan itu sebagai perantara untuk melaksanakan kemauan mereka atau hal yang baik maupun yang jahat. Hanya sedikit orang Melayu yang menganut tradisional atau percaya penuh pada para pemimpinnya. ${ }^{17}$

Kepercayaan tradisional bisa hidup berdampingan dengan Islam, karena mereka berpendapat bahwa sebenarnya Allah-lah yang menyebabkan segala sesuatu, sedangkan hantu, roh jahat, dan setan hanya sebagai perantara. Oleh karena itu jika seseorang hendak menyakiti orang lain yang dibencinya dengan perantara roh jahat atau makhlik halus, ia tidak akan berhasil sebelum Tuhan mengizinkannya. Dengan kata lain kekuatan yang dimiliki roh halus sangat terbatas dan apakah kekuatan mereka efektif atau tidak tergantung pada kekuasaan atau kehendak Allah. Selanjutnya mereka berpendapat bahwa pertolongan apa saja yang dicari dari dukun-dukun tradisional hanya dianggap sebagai suatu ikhtiar, jadi apabila seorang dukun atau pawang melaksanakan tugasnya, ia bertindak atas inisiatifnya sendiri. Apakah inisiatif itu akan berhasil atau tidak tergantung pada kekuasaan Allah.

Meskipun terdapat kecenderungan untuk memperbolehkan adanya ritus-ritus tradisional dan memberikan adanya dukun atau pawang itu atas dasar bahwa mereka tunduk pada kekuasaan Tuhan dan bukan sebagai pengganti kekuasaannya, masih terdapat kecenderungan lain yang menghendaki penghapusan sistem kepercayaan tradisional itu. Hantu, setan dan roh jahat tidak terdapat dalam ajaran Islam. Tentu saja Kitab Suci Al-Quran menyatakan adanya makhluk-makhluk gaib seperti malaikat, jin dan iblis. Tetapi bentuk, asal-usul dan fungsi makhluk-makhluk gaib itu berbeda dari apa yang terdapat dalam kepercayaan tradisional. Lebih lagi karena kepercayaan akan Islam belum tertanam secara kokoh di kalangan rakyat biasa, maka selalu terdapat kemungkinan bahwa kepercayaan mereka akan hantu dan roh jahat dapat menggantikan kepercayaan mereka kepada Allah. Dan itu sama saja dengan politeisme yang dalam agama Islam dianggap dosa.

Kepercayaan tradisional seperti itu masih terus berlangsung dalam masyarakat Melayu Bengkulu, karena kepercayaan itu telah mendarah daging dalam kehidupan dan merupakan bagian dari warisan kebudayaan nenek moyamg. Kepercayaan tradisional itu berkaitan erat dengan nilainilai sosial ekonomis dan kegiatan orangorang Melayu dan selama semuanya itu masih berlangsung maka kepercayaan tradisionalpun akan tetap ada. Meskipun ada kecenderungan menentang kepercayaan tradisionalini namun kecenderungan itu tidak kuat atau efektif. Di daerah pedesaan tidak banyak orang beragama yang 
mengerti atau dapat menyatakan dengan tegas bahwa kepercayaan tradisional itu bertentangan dengan Islam dan harus ditolak. Di daerah pedesaan yang lebih maju meskipun ada pejabat yang berwewenang seperti Kementrian Agama dan pergerakan seperti kelompok misionaris, rupanya mereka belum mampu memberantas kepercayaan tradisional masyarakat Melayu tersebut. Karena kepercayaan tradisional masih berakar kuat di kalangan masyarakat Melayu, tidak salah kalau dikatakan bahwa pada umumnya kepercayaan Islam di kalangan masyarakat Melayu masih perlu dikuatkan lagi. ${ }^{18}$ Misalnya, pengaruh unsur-unsur animisme dan dinamisme di Bengkulu tercermin dalam upacara ritual “Embes Apem" di masyarakat Rejang.

\section{C.Peran Ulama Minang di Bengkulu}

Berbicara mengenai ulama Minangkabau dalam kaitannya dengan proses Islamisasi dan pengembangan pendidikan Islam di Bengkulu, prose ituhinggakinimasih berlangsung secara terus menerus dalam rentang waktu sepanjang abad XVII sampai abad ke XXI. Secara fenomenal kehadiran orang-orang Minang dengan rumah makan Padang dan khas rendangnya di berbagai pelosok negeri Nusantara, bahkan sampai ke negara-negara asing bukanlah suatu yang baru. Lebih dari itu, ulama-ulama Minangkabau yang terkenal sebagai muballigh di rantau antara lain Syekh Ahmad Khatib al-Minangkabawy, Saleh Yasin Padangi di Jawa, Tiga datuk di kerajaan Gowa-Tallo, Datuk RI Bandang, Datuk Pattimang dan Datuk Sulaiman. Itu semua menunjukkan bahwa Minangkabau memiliki peran yang penting dalam penyebaran Islam, termasuk di Bengkulu.

Secara sosio-kultural, masyarakat Minang dengansistem kekerabatannya yang bersifat matrilineal memiliki tradisi merantau. Tradi- si meninggalkan kampung halaman demi mencari kehidupan yang lebih baik. Tradisi merantau itul ebih dipilih pria dewasa etnik Minang dari pada tinggal di kampung sendiri tetapi tidak dihargai karena belum berguna. Di kampung lelaki Minang tidak punya rumah. Tempat mereka tinggal di Surau-surau. Sementara bagi lelaki yang beristeri, dia bisa menginap di rumah isterinya dengan datang malam hari setelah Isya dan harus segera keluar rumah sebelum Subuh. Adapun jika di rantau mereka bisa tinggal dirumah sendiri dari hasil usahanya. Kondisi sosio-kultural inilah yang memotivasi lelaki Minang harus merantau dan harus berhasil di perantauan. Karena kalau gagal di rantau maka akan malu untuk pulang kampung dan kaumnya pun ikut menanggung malu dari kegagalan perantau karena dianggap tidak berguna.

Menurut catatan G.F. Pijper yang pernah ditugaskan mengamati kondisi keagamaan daerah Bengkulu dan sempat berdiskusi dengan Bung Karno saat pembuangannya di Bengkulu, ${ }^{19}$ menyatakan bahwa gerakan Islam modern di Bengkulu berasal dari orang luar Bengkulu mengingat masyarakat Bengkulu jarang meninggalkan tanah airnya untuk menuntut ilmu, karena keterbelakangan mereka. Dua suku yang membawa pengaruh gerakan modernisme Islam menurut Pijper adalah suku Minangkabau dan Suku Jawa. Tokoh pertama yang berhasil dicatat oleh Pijper dalam mengembangkan gerakan modernisme Islam di Bengkulu adalah Haji Ahmad yang berasal dari Minangkabau yang datang ke Bengkulu sebagai pedagang pada tahun 1915. Haji Ahmad mengajarkan agama dengan paham reformis namun tidak terlalu banyak jumlah pengikutnya pada masa itu. ${ }^{20}$

Minangkabau pada masa itu merupakan pusat perkembangan paham reformis Islam yang utama di Pulau Sumatra. Letaknya 
yang tidak terlalu jauh dari Bengkulu menyebabkan pengaruh reformisme Islam dari Minangkabau masuk ke wilayah Bengkulu. Perdebatan kaum Paderi dan kaum Adat yang dilanjutkan dengan perdebatan kaum reformis Islam dengan kaum tardisional Islam terasa kental dan panas pada waktu itu. Kaum reformis Islam bisa disebut dengan kaum muda sedangkan kaum tradisionalis Islam bisa disebut dengan kaumtua/kaumtuo. Meskipun sama-sama bernafaskan reformisme Islam, namun gerakan Paderi dan gerakan kaum mudo sedikit memiliki perbedaan. Munculnya gerakan Paderi bermula dari pulangnya tiga anak Minangkabau dari tanah suci pada tahun 1803. Mereka adalah Haji Miskin, Haji Sumanik dan Haji Piobang, mereka membawa gerakan Syeikh Muhammad bin Abdul Wahab atau sering dikenal dengan gerakan Wahabi.

BJO Schrieke menyimpulkan bahwa duagerakan ini (Paderi dan Whabi) bukanlah gerakan yang sama dan identik. Alasan Schrieke tidak menyamakan gerakan Paderi dan Wahabi karena gerakan Wahabi lebih mengambil jarak dengan empat mazhab yang ada, bahkan mengambil "oposisi" terhadap mazhab-mazhab yang ada, menolak dan mencela pemujaan nabi serta orangorang soleh, namun tidak demikian dengan gerakan Paderi. Gerakan Paderi tidak menyerang sistem Islam yang berkembang secara historis sampai ke akar-akarnya dan tidak terdapat keterangan yang manunjukkan penolakan pemujaan Nabi dan pemujaan orang-orang soleh. Akhirnya, Schrieke menyimpulkan dengan mengutip pendapat Snouck Hurgronje bahwa; "...tindak tanduk kaum Paderi dapat dijadikan alasan mengecapnya sebagai kaum Islam yang soleh, tapi sama sekali tidak dapat dianggap sebagai pengikut aliran Wahabi."21

Sedangkan gerakan kaum Muda, lebih terinspirasi oleh pemikiran Muhammad Abduh dengan majalahnya al-Manar dan majalah al-
Urwatul Wutsqo yang diterbikan oleh Jamaluddin al-Afghani. Pencetus gerakan kaum Muda di Minangkabau ini pada awalnya adalah Syaikh Thaher Djalaluddin. Beliau mendirikan majalah al-Iman yang berpusat di Singapura. ${ }^{22}$ Sementara itu, Steenbrink menyatakan ada satu tokoh utama lagi yang membawakan ajaran Muhammad Abduh ke Minangkabau dan merupakan kawan dari Syaikh Thahir Djalaluddin yaitu Syaikh Abdullah Ahmad yang mendirikan majalah al-Munir dan Sekolah Adabiyah di Padang Panjang. ${ }^{23}$

Bengkulu yang bagian utara wilayahnya berbatasan langsung dengan Sumatera Barat, tentu merupakan daerah tujuan merantau yang sudah dikenal sejak lama. Dalam historiografi tradisional Minang seperti tambo-tambo, cerita-cerita rakyat klasik Minangkabau sudah menyebut nama-nama daerah seperti Ranah Sekalawi dan gunung Bungkuk. Bahkan raja pertama kerajaan Sungai Lemau; Bagindo Maharaja Sakti yang memerintah tahun 16251630 adalah putra Minang yang berasal dari daerah Sungai Tarab (Pagaruyung). Bagindo Maharaja Sakti menikah dengan putri bungsu Akuwu Ratu Agung dari kerajaan Sungai Serut. Ketika Maharaja Sakti bertahta Baginda juga didampingi oleh banyak menteri dan panglima dari kerajaan Pagarruyung. Bagindo Maharaja Sakti dan para pembantunya itu semuanya telah memeluk Islam.

Dalam kaitannya dengan Islamisasi di Bengkulu oleh ulama Minang, tercatat bahwa Syeikh Burhanudin Ulakan (1646-1693) yang merupakan salah satu pendakwah Islam di Minangkabau dengan tarekat Syattariyahnya telah sampai ke Bengkulu pada masa hidupnya. Sampai saat ini tarekat Syattariyah itu sendiri masih eksis baik di Curup, Mukumuko maupun di Kota Bengkulu sendiri. ${ }^{24}$ Selain melalui jalur Tarekat Syat- 
tariyah, proses Islamisasi awal di Bengkulu juga melalui kelompok-kelompok Tarekat Naqsabandiyah Khalidiyah yang muridmuridnya mengembangkan surau suluk di Mukumuko, Bengkulu Tengah dan Rejang Lebong.

Memasuki awal abad ke XX, terutama periode zaman pergerakan Nasional, proses Islamisasi di Bengkulu oleh ulama Minang semakin meningkat. Di daerah Padang Guci Kabupaten Kaur dan Kedurang, Kabupaten Bengkulu Selatan masyarakat mengenal seorang ulama Minang yang mereka sebut sebagai "guru Padang" yang telah berdakwah di sana sejak tahun 1913. Seiring dengan perkembangannya gerakan perkembangan Islam dan sekaligus pembaruan pendidikan Islam melalui organisasi Muhammadiyah, maka didatangkanlah alaumni dari Sumatra Thawalib sebagai mubalig Muhammadiyah dan sebagai guru-guru di sekolah. Para alumni Thawalib itu antara lain: H. Djunus Djamaludin, Ilyas Sutan Perpatih, Buya Fikir Daud, Buya M. Jatim St Besar, Buya Muchtar Jatim, Buya Zainal Abidin Syu'aib, Buya Abdul Malik Sutan Januir, Rasyid Talib, Samsudin Sutan Bandaro nan Sakti, H. Ismail, Buya Abdurrahman Salman, Abdul Azis Sutan Hidayat, Abdul Khalid Sutan Ma'ruf, Ustadz Baharudin dan lain-lain.

Kehadiran para ulama pembaharuan ini dalam catatan Pijper dan Oey Tjeng Hien sempat menimbulkan keributan juga dengan pemerintah kolonial dan masyarakat setempat yang masih memegang adat dan budaya yang berlaku. Hal ini karena watak progresif dan keras ulama-ulama Minang tersebut yang paham ajaran menggelorakan semangat pergerakan dan anti pemerintah kolonial Belanda. Selain melalui jalur organisasi Muhammadiyah, para ulama Minang juga datang melalui Persatuan Tarbiyah Islamiyah (PERTI), di antara tokohnya adalah Buya Abdul Majid dari Batipuh yang mendirikan
Madrasah Tarbiyah cabang PERTI di daerah Lebong. Sedangkan melalui jalur birokrasi pemerintahan di Provinsi Bengkulu, banyak masyarakat Minang yang menjadi tenaga pendidik dari tingkat sekolah dasar sampai perguruan tinggi bahkan menduduki jabatan di pemerintahan.

Dalam kegiatan dakwah di Bengkulu, peran ulama dan masyarakat Minang sangat menonjol. Munculnya organisasi-organisasi dakwah seperti Ikatan Keluarga Masjid Indonesia (IKMI), Korp Muballigh Muhammadiyah (KMM) dan Majlis Dakwah Islamiyah (MDI) tampil para ustadz dari Minang atau keturunan Minang yang berprofesi sebagai guru dan dosen. Beberapa dari mereka kemudian menjadi pimpinan MUI tingkat daerah dan Provinsi. De-ngan demikian, dapat disimpulkan peran dan kiprah ulama Minang dalam Islamisasi di Bengkulu meliputi:

a. Mengenalkan ajaran Tarekat Syatariyah dan Naqsabandiyah dengan membangun surau-surau suluk yang sampai kini masih eksis di Pasar Atas, Curup, Bantal Kabupaten Mukomuko, dan Taba Teret Kabupaten Bengkulu Tengah.

b. Mendirikan organisasi "Muhibbul Ihsan" yang kemudian bergabung dengan Muhammadiyah.

c. Mendirikan dan mengembangkan organisasi Muhammadiyah dengan amal usaha dalam bidang pendidikan dan dakwah.

d. Mengembangkan organisasi Persatuan Tarbiyah Islamiyah (PERTI) dan madrasah-madrasahnya.

e. Menghidupkan aktivitas masjid dengan menjadi Gharim, Imam dan takmir masjid terutama yang dekat dengan pasar. Seperti yang ada di pasar Talo Kabupaten Seluma, terdapat masjid yang didirikan oleh perantau 
Minang H. Muhammad Taib (18701945) yang terkenal sebagai saudagar terkaya di Tais, dengan mendirikan masjid al-Jihad pada tahun 1918 yang merupakan masjid tertua di Seluma dan sampai kini masjid itu masih berdiri kokoh tanpa mengalami perubahan berarti. ${ }^{25}$

f. Mendirikan Yayasan Tawalib yang mengelola pendidikan tingkat dasar dan menengah sejak tahun $1972 .{ }^{26}$

Dengan hadirnya lembaga-lembaga sosial-keagamaan dan yayasan-yayasan pendidikan sebagaimana disebut di atas - yang telah dibangun oleh ulama dan masyarakat Minang di Bengkulu, perkembangan Islam di berbagai wilayah Kabupaten/kota di Provinsi Bengkulu mengalami perkembangan dan kemajuan yang pesat.

\section{Peran Ulama Jawa di Bengkulu}

Hubungan Pulau Jawa dengan Bengkulu telah lama terjalin dengan baik. Ratu Agung yang merupakan raja KerajaanSungai Serut berasal dari Banten. Banten muncul sebagai bandar dagang yang penting terutama dalam perdagangan lada. Sementara, Bengkulu merupakan daerah penghasil lada terbesar yang sempat mengakui Banten sebagai kesultanan di mana mereka bernaung. Akibatnya, arus komunikasi pun terjalin dengan baik termasuk di dalamnya upaya melakukan Islamisasi dari Jawa ke Bengkulu. Di awal abad ke XVIII saat Inggris berkuasa di Bengkulu, adafaktabahwabangsawana Madura telah hadir di Bengkulu. Dalam buku "OrangOrang Besar Bengkulu" karya Agus Setiyanto disebutkan bahwa Panembahan Cakraningrat IV yang memiliki hubungan dekat dengan Inggris memiliki dua orang istri dari Bengkulu. Istri Panembahan itu kemudian melahirkan dua orang putra yaitu Ranadiningrat dan Wirodiningrat. Sementara itu, hubungan antara Cakradiningrat dengan Belanda tidaklah mulus. Ketika terjadi peperangan antara Cakraningrat IV dengan Belanda, dikirimlah Raden Tumenggung Wirodiningrat (anak keempat) dan Raden Sang Nata yang merupakan anak Ranadiningrat ke Bengkulu untuk minta bantuan kompeni Inggris namun upaya itu gagal, mereka akhirnya menetap di Bengkulu. Keluarga bangsawan Madura ini akhirnya diterima dengan baik oleh orang-orang besar pribumi Bengkulu. Perkembangan selanjutnya, keluarga besar keturunan Madura ini berhasil menjalin hubungan pernikahan dengan keluarga besar pribumi setempat dan keluarga besar Madura akhirnya mereka menempati daerah Tengah Padang.

Kehadiran orang-orang dari Pulau Jawa ke Bengkulu mencapai puncaknya ketika dibukanya tambang emas di Lebong pada penghujung abad ke XIX, mereka datang ke Lebong baik suku Sunda maupun Suku Jawa. Selain itu juga dibukanya perkebunanperkebunan besar oleh pemerintah Kolonial Belanda membuat arus deras "kuli-kuli" dari Pulau Jawa. Mereka datang sebagai kuli dan buruh karena ingin merubah nasib dari kemiskinan. Kehadiran orang-orang Jawa ke Bengkulu ini tentu mengikutsertakan budaya, agama dan tradisi. Misalnya, pertunjukan Kuda Kepang adalah salah satu bentuk budaya yang berkembang di tanah Jawa. Sedangkan dari pihak pribumi sendiri, mereka cenderung terbuka untuk menerima kehadiran para pendatang dari daerah lain (Jawa dan Sunda) ke daerah Rejang. Pada aspek lain, adanya kesamaan mazhab fikih yang digunakan oleh para pendatang dari Jawa dengan masyarakat pribumi (Bengkulu) yakni sama-sama menggunakan mazhab Syafi'i. Hal ini menjadi faktor diterimanya kehadiran para pendatang dari Jawa oleh 
masyarakat Bengkulu.

Pada mulanya keberadaan orang Jawa masih terbatas pada area perkebunan dan pertambangan. Mereka bekerja di perkebunan dan pertambangan yang terletak di Rejang Lebong seperti perkebunan Sindang Rejang Cultur yang didirikan pada tahun 1897 dan perusahaan pertambangan Rejang Lebong yang mulai eksploitasi pada tahun 1897. Setelah itu, pemerintah Hindia Belanda membuat program kolonisasi yang diselenggarakan pada tahun 1908. Rombongan pertama muncul pada tahun 1909 yang berasal dari keresidenan Priangan. Mereka didatangkan dengan biaya kas marga dan ditempatkan di Kepahiang. Percobaan ini berhasil dengan berdirinya tiga desa kolonisasi yaitu Permu, Air Sampiang dan Talang Benih. Hal ini terus berlanjut hingga datangnya Jepang di Indonesia. ${ }^{27}$

Gelombang selanjutnya adalah kedatangan guru-guru yang berasal dari Jawa untuk menghidupkan pendidikan di Bengkulu, khususnya di sekolah-sekolah swasta milik Muhammadiyah. Selain sebagai guru mereka juga terlibat sebagai pendakwah. Muallimin Yogyakarta adalah lembaga pencetak guru-guru dan da'i yang dikirim hingga ke pelosok-pelosok negeri tak terkecuali di Bengkulu. Hal ini terjadi setelah kongres Muhammadiyah di Solo pada tahun 1929. Banyaknya guru-guru dan pendakwah yang didatangkan dari Yogyakarta dimaksudkan untuk lebih memperlunak gerakan Muhammadiyah terhadap Hindia Belanda. Sementara, tokoh-tokoh Muhammaduyah dari Minang sesuai dengan sejarah dan budayanya yaitu tak kenal kompromi dan keras dalam dakwahnya. Hal ini membuat Haji Muchtar diminta Asisten Residen untuk hadir ke Bintuhan guna memperlunak gerakan Muhammadiyah yang semakin lama semakin radikal. Ke- mungkinan karena hal tersebut guru-guru dan pendakwah dari Yogyakarta dikirim ke daerah ini, bahkan mereka memperoleh pasangan hidup dan menetap di Bengkulu. Salah satu contohnya adalah Djalal Suyuthie yang menikah dengan salah seorang anak Pesirah dari wilayah Kaur.

Namun, setelah Indonesia merdeka, terutama saat Bengkulu menjadi provinsi baru, banyak tenaga kerja dari Jawa yang didatangkan ke Bengkulu sebagai tenaga pendidik atau sebagi buruh kasar untuk membangun infrastruktur. Selain itu, secara struktural, awalnya banyak orang Jawa yang didatangkan untuk mengisi jabatan-jabatan dalam pemerintahan. Gubernur Soeprapto adalah salah satu contoh sukses orang Jawa yang duduk dalam struktur birokrasi. Gelombang yang paling besar adalah peran program pemerintah yaitu Transmigrasi ke daerah di luar $\mathrm{Pu}$ lau Jawa. Para pendatang Jawa inilah yang membuka hutan-hutan di Bengkulu untuk tempat tinggal dan berkebun mereka, yang akhirnya menjadi derah yang subur dan kaya dengan komoditi karet dan kelapa sawit. Mereka ini kemudian membaur dengan masyarkat setempat, bahkan dari mereka banyak yang menyekolahkan anaknya hingga ke Timur Tengah atupun ke pesantren di Jawa. Ketika meraka pulang, menjadi guru-guru agama yang cukup mumpuni atau malah meniti karir di luar Bengkulu. Peran-peran mereka sangat terasa dalam gerakan Tarbiyah (yang merupakan cikal bakal terbentuknya Partai Keadilan Sejahtera), kelompok Salafi, Muhammadiyah dan Nahdlotul 'Ulama (NU). ${ }^{28}$

Di antara ulama Jawa yang memiliki pengaruh luas adalah K.H. Djalal Suyuthie. Ia lahir di daerah Mangunharjo Yogyakarta pada tahun 1920 dan meninggal pada 12 Februari 1989. Beliau mendapatkan 
bekal-bekal pengetahuan agama langsung dari ayahnya, Djalal Suyuthie juga menuntut ilmu di Muallimin, ${ }^{29}$ salah satu sekolah Muhammadiyah yang cukup terkenal di daerah Yogyakarta. Suyuthie berhasil menamatkan pendidikannya di Muallimin pada tahun 1925. Setamatnya dari Muallimin Suyuthie ditugaskan untuk mengabdi di daerah Padang Guci, Bengkulu, pada tahun $1938 .{ }^{30}$ Selain di Padang Guci, pada fase-fase awal tugas pengabdiannya kepada masyarakat, Suyuthie juga pernah mengabdikan diri dan ilmunya untuk kepentingan pendidikan, sosial dan dakwah di daerah Pasmah dan Lintang, Sumatra Selatan. Melihat latar belakang pendidikannya, dapat ditegaskan bahwa sumber wacana yang secara langsung mempengaruhi pemikiran dan praktek keberagamaan Suyuthie adalah daerah Yogyakarta. Selain itu, mengingat ia juga mendapatkan pendidikan agama yang intensif dalam keluarga di bawah bimbingan ayahnya $\mathrm{H}$. Muhammad Shaleh ${ }^{31}$ dapat diduga bahwa secara tidak langsung wacana keilmuan Suyuthi juga bersumber dari Timur Tengah.

Dalam kaitan dengan sumber wacana yang disebut pertama, jika dihubungkan dengan pemikiran dan paham keagamaan yang diautnya, dapat dipastikan bahwa pemikiran dan praktek keagamaan Suyuthie sangat dipengaruhi oleh pengajaran-pengajaran agama yang diterimanya di sekolah Muallimin, Yogyakarta. Sebagai sekolah yang diperhitungkan dan dapat mengimbangi perkembangan sekolah-sekolah Belanda pada masanya. ${ }^{32}$ Pada awalnya, sekolah Muallimin merupakan lembaga pendidikan yang sistem pendidikannya mirip dengan pesantrendengan mengadopsi sistem dan metode pendidikan modern. Namun setelah berubah menjadi Hogere Muhammadijah School, kurikulumnya ditambah dengan pelajaran ilmu sekuler/umum. Selanjutnya, secara akademik sekolah Muallimin Yogyakarta menerapkan materi kurikulum sekolah yang memadukan ilmu agama dan ilmu sekuler/ umum, seperti yang digagas oleh founding father Muhammadiyah, K.H. Ahmad Dahlan. Kebijakan materi kurikulum ini merupakan perwujudan dari eksperimen K.H. Ahmad Dahlan untuk menebas dikhotomi ilmu-ilmu agama dan ilmu-ilmu umum dalam dunia pendidikan. Melalui sekolah-sekolah Muhammadiyah dan sistem pendidikan yang dikembangkan di dalamnya, pendiri Muhammadiyah ini berharap dapat mendamaikan dua kutub ilmu tersebut. ${ }^{33}$

\section{D.Corak Islam Bengkulu}

Secara historis kehadiran kolonial lnggris dan Belanda ke Bengkulu mengakibatkan terjadinya migrasi penduduk baru dari pulau Jawa, Madura, Bali, Ambon dan Minahasa yang mulai pula berpadu dengan penduduk asli Bengkulu. Kemudian berangsur-angsur pengaruh dari kebisaan para pendatang tersebut ikut memberi warna bagi perkembangan penduduk setempat. Masuknya pengaruh penduduk baru tersebut ke dalam wilayah Melayu Bengkulu itu berlangsung secara damai dan baik, sehingga sukubangsa melayu lebih kelihatan sebagai pemersatu antar sukubangsa yang berbeda-beda. Sukubangsa melayu di Bengkulu telah memperlihatkan corak perkembangan adat-istiadat tersendiri sebagai hasil dari proses adopsi dan asimilasi sukubangsa asli dengan pendatang. Sejalan dengan perkembangan adat-istiadat dari abad ke abad, didukung pula dengan masuknya agama Islam dengan caradamai dan baik, maka adat dan kepercayaan agama Islam ituberpengeruhdalam proses perpindahan langsung dari kepercayaan animisme dan dinamismekedalam Islam. 


\section{E. Adaptasi Islam dengan Budaya Minang- kabau}

Minangkabau adalah suku yang cukup dominan dalam mewarnai budaya Melayu Bengkulu. Pengaruh budaya Minangkabau terlihat pada bahasa Melayu Bengkulu. Panggilan anggota keluarga pun tampak kental dengan pengaruh Minangnya. Jika orang Minang memanggil kakak laki-laki dengan sebutan uda, maka orang Melayu Bengkulu mengadopsinya menjadi udo. Gelar Sutan pun ditransfer dari Minangkabau. Pertalian hubungan budaya Minangkabau-Melayu Bengkulu mulai dibangun setelah pernikahan Maharaja Sakti, bangsawan Pagaruyung (Minangkabau) dengan Putri Gading Cempaka, putri bungsu Ratu Agung, raja Kerajaan Sungai Serut yang runtuh akibat peperangan dengan bala tentara Aceh. Dari pernikahan ini melahirkan kerajaan Baru bernama Sungai Lemau yang berpusat di daerah Pondok Kelapa. Kerajaan Sungai Lemau ini diyakini masyarakat sebagai cikal bakal pertumbuhan dan perkembangan budaya Melayu Bengkulu.

Pada masa pemerintahan Pangeran Mangkuraja (cucu Maharaja Sakti) pusat Kerajaan Sungai Lemau dipindahkan ke Pasar Bengkulu. Tidak lama berselang Mangkuraja mengangkat empat orang keturunan pendamping raja yang berasal dari Again, Simpur, Malalo dan Singkarak Laning. Bahkan keempat orang ini diangkat menjadi Penghulu pasar dengan gelar datuk. Di bawah datuk terdapat pemangku dan di bawah pemangku terdapat penghulu muda. Cepatnya akulturasi bagi orang Minang, menurut sosiolog Minang, Muchtar Naim proses itu terbentuk karena watak budaya Minang yang cenderung untuk bersifat sosialistis dan komunalistis. Kesadaran bermasyarakat yang relatif tinggi di antara mereka, bagaimana pun ada kaitannya dengan proses so- sialistis seperti yang terjadi di desa-desa Minangkabau. Keterikatan mereka kepada surau dan kegiatan agama umumnya menyebabkan orang Miang tidak susah mencarinya di rantau manapun. ${ }^{34}$ Di rantau apabila orientasi berpikir dan keagamaan sejalan dengan orang Minang, maka sangat membantu upaya akultrasi, interaksi, dan asimilasi.

Proses migrasi orang-orang Minang ke Bengkulu memiliki sejarah panjang. Bengkulu sebagai bagian dari pulau Sumatra yang menghadap langsung ke Samudera Hindia (kemudian disebut dengan pantai Barat Sumatera). Mungkin ada orang yang menganggap bahwa pantai Barat Sumatera disamakan dengan Sumatera Barat. Pada hal anggapan tersebut tidak benar, karena wilayah pantai barat Sumatera meliputi pantai Barat Aceh, pantai barat Sumatera Barat (Minangkabau), pantai barat Bengkulu dan pantai barat Lampung. Istilah pantai barat Sumatera yang lebih popular adalah nama untuk kawasan yang meliputi wilayah pesisir barat dari provinsi Sumatra Barat, Tapanuli dan Bengkulu. Perairan pantai barat Sumatera secara otomatis adalah bagian dari perairan Samudera Hindia. Sejak memasuki akhir abad XVII perairan Samudera Hindia telah didatangi oleh para pedagang Inggris dan Belanda. ${ }^{35}$ Kehadiran kedua kelompok dagang tersebut di perairan pantai barat $\mathrm{Su}-$ matera terbatas pada perdagangan, sebab di sepanjang perairan tersebut terdapat beberapa bandar dagang yang berada di garis pantai yang sempit, di Kali Natal, Air Bangis, Tiku, Pariaman, Padang, Salido, Bandar Sepuluh, Muko-muko, Ketahun, Lais, Sungai Lemau, Sungai Serut, Sungai Itam, Sungai Silebar, Manna, Bintuhan dan Krue. Selain orangorang Minangkabau, Batak, Aceh, Bengkulu dan Arab, di pantai barat Sumatera juga berdagang orang Amerika, Perancis dan lain-lain.

Penduduk yang berasal dari Minangka- 
bau mereka cenderung memperlihatkan tingkat mobilitas individual yang tinggi. Mereka sering melakukan perjalanan atau berlayar untuk berniaga, dilihat dari sejarah pantai barat Sumatera menampilkan suasana penuh dinamika penduduknya cenderung berorentasi pada perdagangan, dalam pengertian bahwa mereka telah terbisaa berhubungan dagang dengan para pedagang yang datang dari tempat yang cukup jauh. Dilihat dari mobilitas individu yang tinggi ini bahwa orang-orang yang berasal dari Minangkabau cukup mahir bergelut di dalam dunia perniagaan, setiap kali mereka pergi berniaga ke daerah-daerah yang dituju, jarang sekali mereka gagal dalam hal mencari kehidupan di dalam dunia perniagaan. ${ }^{36}$

Bengkulu merupakan sebuah daerah yang penuh dengan aktivitas ekonomi perdagangan dari hasil perkebunan yang telah lama berlangsung. Namun karena dijajah oleh Inggris dan Belanda selama berabad-abad, Bengkulu tertinggal jauh dari daerah-daerah lain di Indonesia. Komunikasi dan lalu lintas yang sulit mencapai daerah ini menjadi faktor kendala perkembangan dan pertumbuhan Bengkulu. Akan tetapi, faktor perhubungan bukanlah menjadi halangan bagi etnik Minangkabau, orang asing dan orang-orang pendatang dari berbagai daerah. Karena Bengkulu sebagai penghasil lada bagi orang-orang asing seperti Inggris dan Belanda. Begitu juga orang-orang Minangkabau yang datang ke Bengkulu disebabkan sistem perdagangan di Bengkulu sangat menguntungkan seperti emas, kapas dan barang tempahan. ${ }^{37}$

\section{F. Adaptasi Islam dengan Budaya Jawa}

Masuknya budaya Jawa ke Bengkulu tidak terlepas dari kedatangan dua keluarga bangsawan Jawa. Pertama, kedatangan Raden Tumenggung Wiradiningrat beserta sepupunya Raden Sangnata sekitar tahun 1738. Ayah Raden Tumeng- gung Wiradinigrat adalah Panembahan Cakradiningrat, penguasa di Bangkalan Madura yang dibuang ke Tanjung Harapan Afrika Selatan karena memberontak kepada Belanda.Di Bengkulu R. Tumenggung Wiradiningrat menikah dengan anak Daeng Makuleh yang bernama Jariah, sedangkan R. Sangnata menikah dengan Siti Sadiah. Daeng Makkuleh adalah suami Datuk Nyai, putri Pangeran Mangkuraja, raja Kerajaan Sungai Lemau. Tahap kedua adalah kedatangan kelaurga Bangsawan Yogyakarta, di antaranya Sentot Alibasyah yang diasingkan oleh pemerintah Belanda berdasarkan surat pengusulan dari Gubernur Jenderal tertanggal 12 Desember $1843 .^{38}$

Kedatangan dua keluarga bangsawan Jawa tersebut, kemudian beranak pinak dan lama-kelamaan membawa pengaruh luas di tengah-tengah masyarakat Melayu Bengkulu. Kelompok keluarga bangsawan inibegitu dihormati karena berbaur dengan keluarga terhormat lainnya yang berasal dari bangsawan Sungai Lemau dan Bugis. Keluarga bangsawan Jawa menetap di sebuah perkampungan bernama Tengah Padang. Orang Melayu Bengkulu sering mengistilahkan keluarga bangsawan Tengah Padang dengan sebutan Raden-Raden, karena namanama anggota keluarga mereka selalu diawali dengan panggilan Raden. Mengenai dampak budaya dari kedatangan keluarga bangsawan Jawa bagi masyarakat Melayu Bengkulu lainnya tidak begitu menonjol. Di antara pengaruh budaya Jawa, tampak pada tradisi membuat janur penghias tempat acara pernikahan yang umum digunakan masyarakat Melayu Bengkulu.

Keluarga bangsawan Jawa yang datang ke Bengkulu memiliki cara sendiri dalam aturan keluarga dan pergaulan. Di lingkungan keluarga mereka memanggil 
ayah dengan sebutan rama, eyang (untuk nenek/kakek). Kakak perempuan dipanggil dengan mbak dan kakak laki-laki dipanggil dengan mas. Sementara itu, keluarga bangsawan Madura, yang laki-laki semuanya mempergunakan Raden. Apabila belum menikah yang perempuan diberi gelar Raden Ajeng, setelah menikah menyandang gelar Raden Ayu.

Sejalan dengan perkembangan jaman dan proses asimilasi yang berjalan baik, membuat keturunan keluarga bangsawan Jawa di Bengkulu tidak lagi dianggap se-bagai keluarga, kelompok keluarga Tengah Padang telah menyatu dengan masyarakat Melayu Bengkulu yang berasal dari ber-bagai etnis. Ini dapat terlihat dari upacara adat pernikahan yang lebih menonjol budaya Melayu ketimbang Jawa. Panggilan dalam keluarga di lingkungan keluarga keturunan Jawa juga mengalami pergeseran, mereka menggunakan panggilan Melayu Bengkulu seperti inga, dodo, ciknga dan lainnya. ${ }^{39} \mathrm{Hal}$ ini membuktikan adanya proses asimilasi budaya yang cukup baik antar kedua suku, yakni suku Jawa dan suku Melayu Bengkulu.

\section{Kesimpulan}

Perkembangan Islam di Bengkulu saat ini merupakan kelanjutan dari perkembangan Islam sebelumnyan yang dipengaruhi oleh para ulama/intelektual Islam yang berhaluan Islam Ahlussunnah wal Jamaah, dengan penekanan khusus pada teologi Asyariyah dan fiqh mazhab Syafi'i. Di antara ulama/tokoh intelektual yang memiliki keterkaitan dengan Minangkabau dan Jawa antara lain; KH. Abdul Muthalib, K.H. Djamaan Nur, dan K.H. Djalal Suyuthie. Para ulama/tokoh intelektual itu memiliki peran yang sangat strategis dalam mengembangkan ajaran Islam di Bengkulu. Sehingga melahirkan Islam Bengkulu yang memiliki karakteristik tersendiri yaitu Islam akomodatif-adaptif yakni Islam yang tampil dengan warna kental budaya lokalnya. Hal ini karena kebudayaan Melayu Bengkulu merupakan hasil dari pergumulan local genius plus proses sosialisasi dan adaptasi yang panjang antara kebudayaan asli anak negeri Bengkulu dengan kebudayaan lain di se $\neg$ kitarnya, termasuk kebudayaan yang dibawa masuk oleh orangorang pendatang.

\section{Referensi}

Umar Hasyim, Mencari Ulama Pewaris Nabi (Surabaya: PT Bina Ilmu, 1983).

B. Setiawan, et al., Ensiklopedi Nasional Indonesia (Cet. II; Jakarta: PT Cipta Adi Pustaka, 1994), Jilid XVII.

Departemen Pendidikan dan Kebudayaan, Kamus Besar Bahasa Indonesia (Cet. IX; Jakarta: Balai Pustaka, 1997).

Mimbar Ulama, Para Ulama adalah Pewaris Nabi (Jakarta: Suara Majlis Ulama Indonesia, 1999).

Hiroko Horikoshi, Kyai dan Perubahan Sosial, terj. Umar Basalim dan Andi Muarly Sunrawa, (Jakarta: P3M, 1987).

Rosehan Anwar dan Andi Bahruddin Malik (ed.), Ulama dalam penyebaran pendidikan dan Khazanah Keagamaan, (Jakarta: Badan Litbang Agama dan Diklat Keagamaan Depag RI, 2003).

Azyumardi Azra, "Ulama, Politik dan Modernisasi", dalam Ulumul Qur'an, Vol. II 1990/1411 H, No. 7.

George Makdisi, The Rise of College, Institutions of Learning in Islam, (Edinburgh University, 1981).

Yasmadi, Modernisasi Pesantren: Kritik Nurcholish Madjid terhadap Pendidikan Islam Tradisional (Cet. I; Jakarta: Ciputat Press, 2002).

Imam Bawani, Tradisionalisme dalam Pendidikan Islam (Cet. I; Surabaya: al-Ikhlas, 1993).

Sejarah Sosial Daerah KotaBengkulu (Departemen Pendidikan dan Kebudayaan Direk- 
torat Sejarah dan Nilai Tradisional Proyek Inventarisasi dan Dokumentasi Sejarah Nasional tahun 1984).

Pemerintah daerah Provinsi Bengkulu, Kenang-Kenangan Perjuangan Bekas Keresidenan Bengkulu Menjadi Provinsi Bengkulu (Palembang: Sriwijaya Media Utama, 1993).

Tim Penulis Inventarisasi Perlindungan Karya Budaya: Aksara Ka Ga Nga Di Bumi Raflesia. (Kementerian Pendidikan Dan Kebudayaan Balai Pelestarian Nilai Budaya Padang Tahun 2012).

Menurut data, pada awal pembentukan Provinsi Bengkulu luas wilayahnya mencapai 26.249, $4 \mathrm{~km} 2$, berdasarkan sumber tulisan dari buku Kementerian Penerangan tentang Republik Indonesia mengenai Sumatera Selatan. Pemerintah Daerah Provinsi Bengkulu, tahun 1993.

S. Husin Ali, Rakyat Melayu Nasib dan Masa Depannya, (Jakarta: Inti Sarana Aksara, 1985).

M.Ali Chanafiah, Bung Karno Dalam Pengasingan Di Bengkulu, (Jakarta: Aksara Press). Dalam Salim Bella Pilli, Hardiansyah, Napak Tilas Muhammadiyyah Bengkulu (Membangun Islam Berkemajuan di Bumi Raflesia), (Yogyakarta: Valia Pustaka, 2016).

G.F. Pijper, Fragmenta Islamica: Beberapa Studi Mengenai Sejarah Islam di Indonesia Awal Abad XX (Terjemah Tujdimah), (Jakarta: UI Press, 1987).

BJO Schrieke, Pergolakan Agama di Sumatra Barat, (Jakarta: Bhratara, 1973).

Hamka, Sejarah Perkembangan dan Pemurnian Ajaran Agama Islam di Indonesia: Pidato Hamka saat menerima Gelar Doktor Honoris CausaDari Al-Azhar University Mesir Pada Tanggal 21 Januari 1958, (Jakarta: Tintamas, 2008).

Karel A Stennbrink, Pesantren, Madrasah dan Sekolah: Pendidikan Islam Dalam Kurun Modern (Jakarta: LP3ES, 1986).

Informasi mengenai masjid al-Jihad tersebut dimuat dalam berita "Koran Rakyat Bengkulu", 21 Desember 2014.

Mahmud Yunus, Sejarah Pendidikan Islam Di Indonesia (Jakarta: Hidakarya Agung, 1984).

Disarikan dari hasil wawancara dengan $\mathrm{H}$. Djazari Saleh (adik kandung K. H. Djalal
Suyuthie) pada tanggal 21 September 2014. M. Nur, Pelabuhan Bengkulu dan Perdagangan Pada Masa Kolonial Inggris, (Padang, Kementrian Kebudayaan dan Pariwisata, BKSNT, 2004).

Sartono Kartodirjo, Pengantar Sejarah Indonesia Baru; 1500-1900 dari Emporium Sampai Imperium, (Jakarta, Gramedia Pustaka Utama, 1993).

Dokumentasi Sejarah Nasional, Sejarah Sosial Kota Bengkulu, (Dapertemen Pendidikan dan Kebudayaan Jakarta, 1984).

${ }^{1}$ Umar Hasyim, Mencari Ulama Pewaris Nabi (Surabaya: PT Bina Ilmu, 1983), hlm. 14.

${ }^{2}$ Dalam QS. Fathir, Allah swt. Berfirman: "Sesungguhnya (hamba/manusia) yang paling takut kepada Allah swt diantara hamba-hambya-Nya hanyalah para ulama."

${ }^{3}$ B. Setiawan, et al., Ensiklopedi Nasional Indonesia (Cet. II; Jakarta: PT Cipta Adi Pustaka, 1994), Jilid XVII, hlm. 25.

${ }^{4}$ Departemen Pendidikan dan Kebudayaan, Kamus Besar Bahasa Indonesia (Cet. IX; Jakarta: Balai Pustaka, 1997), hlm. 1098.

${ }^{5}$ Mimbar Ulama, Para Ulama adalah Pewaris Nabi (Jakarta: Suara Majlis Ulama Indonesia, 1999), hlm. 34.

${ }^{6}$ Hiroko Horikoshi, Kyai dan Perubahan Sosial, terj. Umar Basalim dan Andi Muarly Sunrawa, (Jakarta: P3M, 1987), hlm. 114.

${ }^{7}$ Sebagaimana dikutip Rosehan Anwar dan Andi Bahruddin Malik (ed.), Ulama dalam penyebaran pendidikan dan Khazanah Keagamaan, (Jakarta: Badan Litbang Agama dan Diklat Keagamaan Depag RI, 2003), hlm. 38.

${ }^{8}$ Azyumardi Azra, "Ulama, Politik dan Modernisasi", dalam Ulumul Qur'an, Vol. II 1990/1411 H, No. 7, hlm. 6.

${ }^{9}$ George Makdisi, The Rise of College, Institutions of Learning in Islam, (Edinburgh University, 1981), hlm. 27.

${ }^{10}$ Yasmadi, Modernisasi Pesantren: Kritik Nurcholish Madjid terhadap Pendidikan Islam Tradisional (Cet. I; Jakarta: Ciputat Press, 2002), hlm. 63.

${ }^{11}$ Imam Bawani, Tradisionalisme dalam Pendidikan Islam (Cet. I; Surabaya: al-Ikhlas, 1993), hlm. 90. 


\begin{abstract}
${ }^{12}$ Dalam Sejarah Sosial Daerah KotaBengkulu (Departemen Pendidikan dan Kebudayaan Direktorat Sejarah dan Nilai Tradisional Proyek Inventarisasi dan Dokumentasi Sejarah Nasional tahun 1984), hlm, 3-4.

${ }^{13}$ Untuk lebih jelasnya mengenai data ini lihat dalam Pemerintah daerah Provinsi Bengkulu, Kenang-Kenangan Perjuangan Bekas Keresidenan Bengkulu Menjadi Provinsi Bengkulu (Palembang: Sriwijaya Media Utama, 1993), hlm. 27. Dalam Tim Penulis Inventarisasi Perlindungan Karya Budaya: Aksara Ka Ga Nga Di Bumi Raflesia. (Kementerian Pendidikan Dan Kebudayaan Balai Pelestarian Nilai Bu-
\end{abstract} daya Padang Tahun 2012), hlm, 15.

${ }^{14}$ Menurut data ini, pada awal pembentukan Provinsi Bengkulu luas wilayahnya mencapai 26.249, $4 \mathrm{~km} 2$, berdasarkan sumber tulisan dari buku Kementerian Penerangan tentang Republik Indonesia mengenai Sumatera Selatan. Pemerintah Daerah Provinsi Bengkulu, tahun 1993, hlm. 27. Tertuang dalam Tim Penulis Inventarisasi...hlm. 15.

${ }^{15}$ Tim Penulis Aksara Ka Ga Nga..., hlm. 16.

${ }^{16}$ S. Husin Ali, Rakyat Melayu Nasib dan Masa Depannya, (Jakarta: Inti Sarana Aksara, 1985), hlm. 56-57.

${ }^{17}$ Ibid..,hlm. 58-59.

${ }^{18}$ Ibid..,hlm. 61-62.

${ }^{19}$ M.Ali Chanafiah, Bung Karno Dalam Pengasingan Di Bengkulu, (Jakarta: Aksara Press). Dalam Salim Bella Pilli, Hardiansyah, Napak Tilas Muhammadiyyah Bengkulu (Membangun Islam Berkemajuan di Bumi Raflesia), (Yogyakarta: Valia Pustaka, 2016), hlm. 72.

${ }^{20}$ G.F. Pijper, Fragmenta Islamica: Beberapa Studi Mengenai Sejarah Islam di Indonesia Awal Abad XX (Terjemah Tujdimah), (Jakarta: UI Press, 1987), hlm. 134-135. Dalam Salim Bella Pilli, Hardiansyah, Ibid, hlm. 73.

${ }^{21}$ BJO Schrieke, Pergolakan Agama di Sumatra Barat, (Jakarta: Bhratara, 1973), hlm. 15-18. Dalam, Salim Bella Pilli, Ibid.., hlm. 74.

${ }^{22}$ Hamka,Sejarah Perkembangan dan Pemurnian Ajaran Agama Islam di Indonesia: Pidato Hamka saat menerima Gelar Doktor Honoris CausaDari Al-Azhar University Mesir Pada Tanggal 21 Januari 1958, (Jakarta: Tintamas, 2008), hlm. 13. Dalam Salim Bella Pilli, Hardiansyah,...hlm. 74.

${ }^{23}$ Karel A Stennbrink, Pesantren, Madrasah dan Sekolah: Pendidikan Islam Dalam Kurun Modern (Jakarta: LP3ES, 1986), hlm. 39. Dalam Ibid.., hlm. 74 .

${ }^{24}$ Pada bulan September 2017 peneliti melakukan dialog langsung dengan tokoh Tarekat Syattariyah yang ada di wilayah Kota Bengkulu; Bapak Yasrul (65 tahun), Bapak Ali Amran (63 tahun), dan Bapak Arius (40 tahun).

${ }^{25}$ Informasi mengenai masjid al-Jihad tersebut dimuat dalam berita "Koran Rakyat Bengkulu", 21 Desember 2014, hlm. 27.

${ }^{26}$ Salim Bella Pilli, Ibid.., hlm. 85-87.

${ }^{27}$ Mahmud Yunus, Sejarah Pendidikan Islam Di Indonesia (Jakarta: Hidakarya Agung, 1984), hlm. 78-79.

${ }^{28}$ Salim Bella Pilli, Hardiansyah, Napak Tilas..., hlm. hlm.87-90.

${ }^{29}$ Madrasah Mu'allimin Muhammadiyah Yogyakarta didirikan oleh KH Ahmad Dahlan pada tahun 1918, terletak di Kampung Kauman Yogyakarta. Pada awalnya, madrasah ini bernama dengan nama madrasah "Qismul Arqa", dan sepanjang sejarahnya, Madrasah ini telah beberapa kali mengalami perubahan nama; dari Madrasah al-Qismul Arqo kemudian berganti menjadi Hogere Muhammadijah School, kemudian berganti nama menjadi Kweekschool Islam, selanjutnya berganti nama menjadi Kweekschool Muhammadijah. Pada awalnya, sekolah ini bertempat di Kauman, selanjutnya dipindahkan ke Ketanggungan Wirobrajan (sekarang Jl. Letjend. S. Parman 68). Perubahan nama menjadi Madrasah Mu'allimin Muhammadijah terjadi pada tahun 1941, berdasar hasil kongres Muhammadyah ke-23 yang diselenggarakan pada 19-25 Juli 1934 di Yogyakarta, dan nama inilah yang dipergunakan sampai sekarang. Perubahan nama ini bermula dari kritik para warga Muhammadiyah, mengapa harus memakai nama sekolah Belanda; Kweekschool, padahal ijazahnya dan kurikulumnya jelas berbeda. Saat gempa bumi mengguncang kota Yogyakarta pada 26 Mei 2006, bangunan sekolah ini mengalami kerusakan yang parah, yang membuat bangunannya harus dihancurkan. Atas inisiatif dari Ahmad Syafii Maarif, mantan Ketua Umum Pimpinan Pusat Muhammadiyah yang juga alumni madrasah ini, kemudian dilakukan penggalangan dana untuk membangun bangunan utama Muallimin. Pada awal tahun 2008, bangunan utama ini berhasil 
dibangun kembali.

${ }^{30}$ Disarikan dari hasil wawancara dengan H. Djazari Saleh (adik kandung K. H. Djalal Suyuthie) pada tanggal 21 September 2014.

${ }^{31}$ Seperti dituturkan Djazari Saleh, semasa hidupnya, H. Muhammad Shaleh merupakan salah seorang tokoh yang cukup berperan dalam pendidikan agama di daerahnya. Selain mengajar Al-Qur'an dan dasar-dasar ilmu agama kepada anak-anaknya secara intensif, ia juga mengajar buruh-buruh tani yang tinggal di rumahnya pada waktu sebelum atau sesudah shubuh.

${ }^{32}$ Hery Noer Aly, dkk, "Laporan Penelitian Kelompok".., hlm. 91.

${ }^{33}$ Mengenai latar belakang pendirian Muallimun, versilainnya menyebutkan bahwa pendirian sekolah ini dilatarbelakangi oleh tuntutan para alumni Sekolah Rakyat (sekolah Ongko Loro) milik Muhammadiyah yang tidak bisa melanjutkan ke sekolah guru milik gubernemen. Informasi ini diperkuat oleh artikel dalam Soeara $\mathrm{Mu}$ - hammadijah terbitan Januari 1922, yang menyebutkan bahwa al-Qismu al-Arqo merupakan sekolah lanjutan Sekolah Kelas Dua (Ongko Loro). Muhammadiyah beberapa kali mengajukan permohonan persamaan ijazah dengan rekomendasi Boedi Oetomo, namun tidak juga diterima.

${ }^{34}$ Ibid..,hlm. 278.

${ }^{35}$ M. Nur, Pelabuhan Bengkulu dan Perdagangan Pada Masa Kolonial Inggris, ( Padang, Kementrian Kebudayaan dan Pariwisata, BKSNT, 2004), hlm, 16.

${ }^{36}$ Sartono Kartodirjo, Pengantar Sejarah Indonesia Baru; 1500-1900 dari Emporium Sampai Imperium,( Jakarta, Gramedia Pustaka Utama, 1993), hlm, 115.

${ }^{37}$ Dokumentasi Sejarah Nasional, Sejarah Sosial Kota Bengkulu, (Dapertemen Pendidikan dan Kebudayaan Jakarta, 1984), hlm. 51.

${ }^{38}$ Ibid.., hlm. 52.

${ }^{39} \mathrm{Ibid}, \mathrm{hlm} .279$. 